\title{
THE USE OF STREPTOMYCIN (DIHYDROSTREPTOMYCIN SULFATE) IN THE TREATMENT OF FOWL CORYZA OR "MOQUILLO"
}

\author{
J.D. Rivera-Anaya, J.Martinez de Jesús, and R.Orlandi ${ }^{1}$
}

\section{INTRODUCTION}

The poultry and egg business in Puerto Rico had an average yearly value of $\$ 10,600,000$ from 1944 to 1948 . Importations of poultry meat and eggs from the United States of America and foreign countries amounted to $\$ 3,139,000$ in $1949-50$.

The need for expansion of the poultry business is apparent when we consider that importations during $1949-50$ were valued at over $\$ 3,000,000$. Diseases of poultry are important among the many obstacles that handicap the business and prevent its expansion. Among the diseases that affect poultry on the Island, coryza or "moquillo" is common and economically important.

\section{NATURE OF “MOQUILLO" AND ITS CONTROL}

Beach $(1)^{2}$ considered coryza the most common and widespread of all poultry diseases. Certain environmental conditions, such as overcrowding, dampness, poor ventilation, and sudden changes in temperature, aid in its establishment and spread.

The etiological agent of "moquillo" has been determined to be a pleomorphic polar-staining hemophyllic bacillus called Hemophilus gallinarum. The disease is remarkably variable in severity and virulence, depending upon the character of the complications and the number of birds affected. The symptoms of coryza include nasal discharge, droopiness and general dejection, diminished appetite or anorexia, swelling of the face and wattles, sinusitis, conjunctivitis, tracheitis, bronchitis, and infection of the air sacs, with gasping and coughing. The birds often become emaciated.

The disease usually has a prolonged course, extending over several weeks, or even months. Mortality may reach 50 percent of the affected birds, and usually results from suffocation (asphyxia) as a result of the involvement of the lower respiratory tract.

Definite diagnosis of coryza, according to Beach (1), requires the determination of transmissibility by contact with healthy birds or alternatively by intranasal inoculation of healthy birds with exudate from affected ones,

1 Associate Veterinarian, Research Assistant in Bacteriology, and Assistant Bacteriologist, respectively, Agricultural Experiment Station, University of Puerto Rico, Río Piedras, P. R.

${ }_{2}$ Numbers in parentheses refer to Literature Cited, p. 58. 
and the demonstration of H. gallinarum under the microscope. "Moquillo" may be confused with other diseases like fowl cholera, laryngotracheitis, and nutritional deficiencies like A-avitaminosis. Transmission and crossprotection tests are often necessary to differentiate between coryza and infectious laryngotracheitis. Microscopic and cultural laboratory methods are frequently required to distinguish "moquillo" from fowl cholera.

Recommendations for the control and treatment of coryza have included segregation and sometimes destruction of affected flocks; disinfection of nasal passages of sick birds with nonirritating substances such as boric acid, menthol, or liquid petrolatum; destruction of severely affected animals; incision and drainage of the sinuses; strict sanitation of utensils and premises; correction of any inadequate housing or managerial practice; and feeding of a 1-percent sulfathiazole mix. Treatment has not been too successful, and birds that recover are regarded as carriers, thus increasing the complexity of control.

Mr. Ramón Rosa Alvarado, an Extension county agent, reported apparent beneficial results from the use of streptomycin injections in a limited number of valuable game-birds. With this information to go on the authors decided to evaluate the possibilities of streptomycin as a treatment for coryza. The first four trials described below were carried out at the Río Piedras Station during July and August 1949. The last two were undertaken at the La Plata (Aibonito) Substation in colony hen houses, during July and August 1951.

\section{EXPERIMENTAL METHODS AND RESULTS WITH STREPTOMYCIN}

\section{Trial No. 1}

Twelve young birds about $31 / 2$ months old, and weighing about 3 pounds each, with clinical symptoms of "moquillo" were paired off in a 6-cage, 3tier battery. One of the two birds in each cage was subcutaneously injected in the pectoral area with $0.25 \mathrm{gm}$. of dihydrostreptomycin sulfate in $1 \mathrm{cc}$. of sterile, distilled water. The second bird of the pair was left in the cage as an infected, untreated control.

Clean, fresh water was kept before the birds at all times; a commercial feed mixture was provided. The battery was washed, disinfected, and sun-dried before putting the birds in, and was cleaned daily during the test.

Observations were made on the birds individually at 24-hour intervals, for 5 days. Each bird was checked for nasal discharge daily, by pressing with the thumb over the nasal openings.

Five of the six birds with coryza which were treated subcutaneously with $0.25 \mathrm{gm}$. of streptomycin, were found free of nasal discharge 48 hours later. Two of these birds were negative 24 hours after injection. While all six 
control birds remained infected, 83.33 percent of the treated birds responded favorably, even in the presence of infected battery mates throughout the experimental period.

This preliminary trial definitely established the value of streptomycin in controlling fowl coryza, corroborating results informally reported to us. Further trials were made to determine the proper dosage and the best method of administering it.

\section{Trial No. 2}

Forty-eight young birds about $3 \frac{1}{2}$ months old and weighing about 3 pounds each were placed in groups of six in an 8-cage, 4-tier battery which had been washed, disinfected, and sun-dried before use. Management was as outlined for trial No. 1 . All 48 birds showed clinical symptoms of coryza. Of each group of six birds, two were injected subcutaneously with $0.10 \mathrm{gm}$. of dihydrostreptomycin sulfate in $1 \mathrm{cc}$. of sterile, distilled water; two were similarly injected with $0.05 \mathrm{gm}$. of the antibiotic; two were left as infected, untreated controls. Injections were made in the pectoral area.

Observations were made on the individual birds twice daily for 4 days, starting 18 hours after injection. Four of the sixteen infected controls died from coryza during the experimental period; two died within 48 hours after the start of the experiment, and the other two within 76 hours. All of the surviving 12 controls remained infected. Two of the sixteen birds given subcutaneous doses of $0.10 \mathrm{gm}$. of streptomycin and one of the sixteen birds given subcutaneous doses of $0.05 \mathrm{gm}$. of streptomycin, were free from nasal discharge and other symptoms of coryza, and were considered cured.

The criterion established for a "cure" was the disappearance of the characteristically offensive nasal discharge for a minimal period of 48 consecutive hours. Thus, 12.5 percent of the birds dosed with $0.10 \mathrm{gm}$. were regarded as cured as compared with only 6.3 percent ( 1 out of 16 birds) of those dosed with $0.05 \mathrm{gm}$.

\section{Trial No. 3}

Forty-four young birds showing symptoms of "moquillo" were distributed in four groups of five birds, and four groups of six birds each, in an 8 -cage, 4-tier battery. Two birds in each group were subcutaneously injected in the pectoral area with $0.10 \mathrm{gm}$. of dihydrostreptomycin sulfate in $1 \mathrm{cc}$. of sterile, distilled water; two other birds per group were similarly injected with $0.05 \mathrm{gm}$. of the antibiotic. In four groups, two infected, untreated birds were left as controls, whereas only one control bird per group was left in the other four groups. Handling and management were as outlined above for previous trials. 
Observations were made on the individual birds twice daily for 6.5 days, starting 24 hours post-injection. One of the twelve infected controls died from coryza during the observation period and within 48 hours after the start of the experiment. The 11 surviving controls were still infected at the end of the experiment.

Three of the sixteen birds (18.7 percent) injected subcutaneously with individual 0.10 -gm. doses of streptomycin apparently remained free from coryza. Three of the sixteen birds ( 18.7 percent) dosed with $0.05 \mathrm{gm}$. also were regarded as cured.

\section{Trial No. 4}

Forty-eight young birds with clinical signs of "moquillo" were housed, handled, and managed as outlined for the previous trials. The birds were placed six to a group, two being infected, untreated controls, two being treated with $0.10 \mathrm{gm}$. of dihydrostreptomycin sulfate, and two with 0.05 gm. as outlined above. Observations were made on the individual birds twice daily for 15 days, starting 24 hours post-injection. During this observation period of 15 days, 4 of the 16 infected controls died from coryza. None of the surviving controls recovered from the infection.

Six of the sixteen birds (37.5 percent) treated subcutaneously with $0.10 \mathrm{gm}$. of streptomycin recovered from coryza during the 15 day observation period. Two of the remaining ten birds treated with $0.10 \mathrm{gm}$. died from coryza. Only four of the sixteen birds (25 percent) in the 0.05 -gm. group recovered from coryza.

\section{Trial No. 5}

One hundred and forty birds with clinical symptoms of coryza were divided into four groups of $30,35,35$, and 40 individuals each. Each group was subdivided into infected, untreated controls, and birds treated with $0.10,0.15,0.20$, and $0.25 \mathrm{gm}$. of dihydrostreptomycin sulfate. Each individual dose was dissolved in 1-cc. of sterile, distilled water. Infected controls were injected with $1 \mathrm{cc}$. of unmedicated, sterile distilled water. All injections were made intramuscularly in the pectoral area. Twenty-eight birds were included in each dosage-treatment and control group

Observations were made on individual birds at 24-hour intervals, for 21 days, starting 1 day after injection. Handling and management followed the pattern outlined for previous trials. Eight of the twenty-eight infected control birds (28.6 percent) were considered negative at some time during the 21-day observation period. Seven of the eight negative birds were found in one hen house; one of these negative birds died later on during the observation period. We have no plausible explanation for these apparently spontaneous recoveries. The remaining 20 birds in the 
control group carried the infectious coryza throughout the experimental period.

Twenty-six of the twenty-eight birds (92.9 percent) treated with single intramuscular injections of $0.10 \mathrm{gm}$. of streptomycin were apparently freed from coryza. One of the negative birds died during the 21-day observation period. A single intramuscular injection of $0.15 \mathrm{gm}$. of streptomycin was successful in curing 21 of the 28 birds so treated ( 75 percent). One of the seven birds in this group that failed to respond to the treatment died from

TABLE 1.-Effectiveness of streptomycin in controlling coryza or " moquillo" in chickens, by dosage, and method of administration

\begin{tabular}{|c|c|c|c|c|c|c|c|}
\hline \multirow{3}{*}{ Trial No. } & \multicolumn{2}{|c|}{ Dosage used- } & \multicolumn{5}{|c|}{ Infected birds used and results } \\
\hline & \multirow{2}{*}{$\begin{array}{c}\begin{array}{c}\text { Subcuta- } \\
\text { neously }\end{array} \\
\text { Grams }\end{array}$} & \multirow{2}{*}{$\begin{array}{c}\text { Intramus- } \\
\text { cularly }\end{array}$} & \multirow{2}{*}{$\begin{array}{c}\text { Total } \\
\text { Number }\end{array}$} & \multirow{2}{*}{$\begin{array}{l}\text { Treated } \\
\text { Number }\end{array}$} & \multirow{2}{*}{$\begin{array}{l}\text { Control } \\
\text { Number }\end{array}$} & \multicolumn{2}{|c|}{ Cured } \\
\hline & & & & & & Number & Percent \\
\hline 1 & 0.25 & $\ldots$ & 12 & 6 & 6 & 5 & 83.3 \\
\hline & $\{.10\}$ & $\ldots$ & & $\{16\}$ & $16^{1}$ & $\int 2$ & 12.5 \\
\hline 2 & $\mid .05$ & $\ldots$ & 48 & 16 & & 1 & 6.3 \\
\hline & $\{.10\}$ & $\cdots$ & & $\{16\}$ & $11^{2}$ & 3 & 18.7 \\
\hline 3 & .05 & $\cdots$ & 43 & (16) & & 3 & 18.7 \\
\hline & $\{10\}$ & $\ldots$ & & $\left\{16^{3}\right\}$ & $16^{4}$ & 6 & 37.5 \\
\hline 4 & $\mid .05\}$ & & 48 & 16 & & 4 & 25.0 \\
\hline & $\ldots$ & $(0.10)$ & & $\left(28^{5}\right)$ & & 26 & 92.9 \\
\hline & $\ldots$ & $\{15\}$ & 140 & $28^{5}$ & & 21 & 75.0 \\
\hline & $\ldots$ & $.20\}$ & & $28\}$ & $20^{\circ}$ & 27 & 96.4 \\
\hline 5 & $\ldots$. & .25 & & 28 & & 24 & 85.7 \\
\hline 6 & $\ldots$ & .10 & 697 & 697 & & 675 & 97.0 \\
\hline
\end{tabular}

14 birds died during observation period.

21 control bird died during observation period.

${ }^{3} 2$ birds died during observation period.

${ }^{4} 4$ control birds died during observation period.

${ }^{5} 1$ of the treated and 1 of the control birds died during observation period.

coryza during the observation period. Twenty-seven of the twenty-eight birds (96.4 percent) injected intramuscularly with $0.20 \mathrm{gm}$. of streptomycin apparently recovered from the coryza infection during the observation period, while 24 of the 28 birds similarly treated with 0.25 -gm. doses $(85.7$ percent) responded favorably.

One hundred and six birds (75.5 percent of the 140 in the trial) were regarded as "cured" at some time during the experimental period, eight of these being in the untreated, infected control group.

One hundred and twelve birds were treated at one of the four dosage levels of streptomycin used. The antibiotic apparently cleared up infectious coryza in 87.5 percent of them (98 birds). 
Trial No. 6

A total of 697 cockerels and pullets with clinical signs of coryza, grouped in colony houses, was handled and managed as outlined above for previous trials. Each bird was injected with $0.10 \mathrm{gm}$. of dihydrostreptomycin sulfate in $1 \mathrm{cc}$. of sterile, distilled water. Injections were made intramuscularly in the pectoral region. All the birds were injected, none being left as controls.

Observations on individual birds were made 3 and 6 days after injection. Observations made 3 days after treatment revealed that 663 of the birds were free from coryza. A second observation made 3 days later showed that a total of 675 (97 percent) of the 697 birds had apparently recovered from the infection.

\section{Results from all trials}

For the convenience of the reader the results from all six trials to determine the effectiveness of streptomycin in the control of chicken coryza are presented in table 1.

\section{SUMMARY AND CONCLUSIONS}

We are of the opinion that the use of streptomycin injections is definitely benefitial in controlling infectious coryza of chickens.

Seventy of the seventy-eight infected, untreated control birds did not recover from coryza; 10 of these control birds died from coryza infection during the observation periods; 8 birds in the control group made an apparently spontaneous recovery for which we have no valid explanation.

Whereas any treatment with streptomycin injection proved better than no treatment, the lowest dose used in these trials, i.e., $0.05 \mathrm{gm}$. subcutaneously per bird, did not seem to be effective in a large proportion of the birds treated under our experimental conditions.

A single $0.10-\mathrm{gm}$. dose of streptomycin per bird proved to be more effective in curing and checking coryza than the 0.05 -gm. dose. The effectiveness of the $0.10-\mathrm{gm}$. dose used subcutaneously, varied from 12.5 to 37.5 percent when the coryza-infected birds were kept in batteries in the presence of infected, untreated controls.

When the single $0.10-\mathrm{gm}$. dose was injected intramuscularly, its effectiveness increased to 92.9 percent, even in the presence of infected, untreated controls in the same hen house.

The effectiveness of the 0.15 -gm. intramuscular dose was 75 percent.

The highest effectiveness, 96.4 percent, was noted when a single intramuscular 0.20 -gm. dose was used per bird.

The 0.25 -gm. dose had an effectiveness of 83.3 percent when injected subcutaneously, and 85.7 percent intramuscularly. 
We believe that the cost of the higher streptomycin dosage-levels $(0.20$ and $0.25 \mathrm{gm}$.) may preclude their extensive use in commercial poultry flocks, especially so when their respective effectiveness is not substantially (significantly) greater than that of lower, cheaper streptomycin doses.

The use of a single, intramuscular dose of $0.10 \mathrm{gm}$. of streptomycin per bird affected seems to be an economical, efficient, and reliable means for the control of infectious coryza or "moquillo" of poultry.

\section{RESUMEN}

Las inyecciones de estreptomicina son eficaces para controlar el "moquillo" de las aves.

Las aves que se trataron con la estreptomicina mejoraron o curaron del "moquillo" en una proporción mayor que las que se dejaron sin administrarle la droga. Sin embargo, es bueno apuntar, que la concentración de 0.05 gramo de estreptomicina, la más baja en los ensayos, aplicada subcutáneamente a cada ave, dejó de surtir los efectos de curación esperados.

Cuando se inyectó la estreptomicina en concentraciones de $0.10,0.15$, 0.20 , y 0.25 gramo por ave, la eficacia de la droga en contra de la enfermedad fué de $92.9,75.0,96.4$ y 85.7 porciento, respectivamente.

Las inyecciones intramusculares fueron más eficaces que las subcutáneas.

De acuerdo con los resultados, el aplicar una inyección intramuscular de 0.10 gramo de estreptomicina por ave enferma, es un método económico y casi seguro para controlar el "moquillo" aviar.

\section{LITERATURE CITED}

1. Beach, J. R., Infectious Coryza, pp. 303-7, Diseases of Poultry, by Biester, H. E., and De Vries, Louis, The Collegiate Press, Inc., Ames, Iowa, 1944. 